УДК 376

DOI https://doi.org/10.24919/2308-4863/35-1-41

Оксана БОРЯК,

orcid.org/0000-0003-2484-1237

доктор педагогічних наук, дочент,

професор кафедри спеціальної та інклюзивної освіти Сумського державного педагогічного університету імені А. С. Макаренка (Суми, Украӥна) oksana_boriak@ukr.net

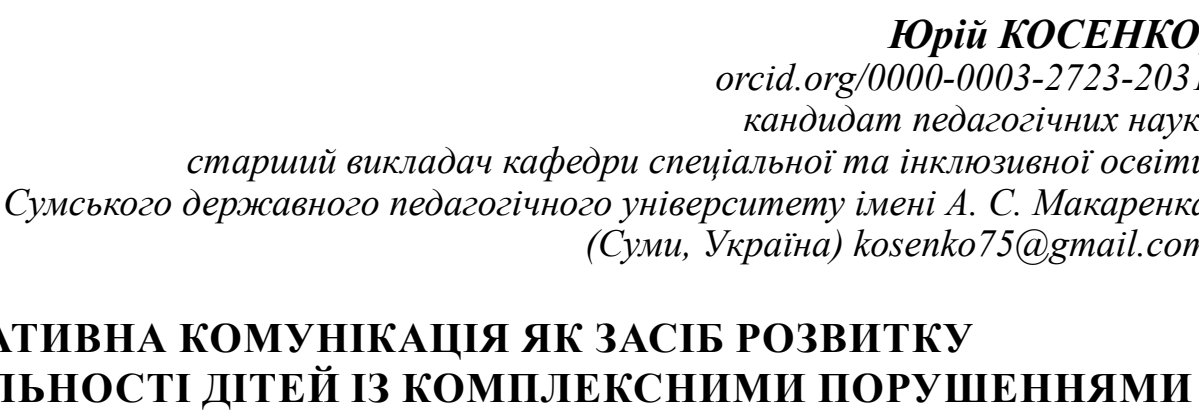

У статті представлено результати дослідження визначення поняття «альтернативна комунікація» в спеціальній освіті, обтрунтовано ї̈ вплив на розвиток мовлення дітей з комплексними порушеннями розвитку - тяжкими порушеннями мовлення, зумовленими інтелектуальними порушеннями помірного ступеня тяжкості.

Мета статті - дослідити та обтрунтувати доцільність використання альтернативних засобів комунікації як ефективного засобу розвитку мовлення у дітей із комплексними порушеннями.

Під час дослідження було з'ясовано, щзо альтернативна комунікація - ие спосіб навчити $i$, за можливістю, компенсувати постійні чи тимчасові порушення, які призводять до обмеження суспільного життя $і$ сочіальної взаємодї осіб з комплексними порушеннями розвитку, за яких фіксуються порушення сприймання і відтворення мови і мовлення, як усного, так і писемного. Альтернативні засоби комунікації розглядаються в спеціальній освіті як засоби первинної комунікації для дітей різного віку, які знаходяться в домовленнєвому періоді розвитку; засоби комунікації, які частково або повністю замінюють усне мовлення. Було виявлено, щуо сьогодні в спеціальній освіті не розглядалось питання розвитку комунікативних навичок у дітей, які мають комплексні (комбіновані) порушення розвитку, а саме - порушення інтелектуального розвитку та мовлення. Визначити особливості комунікативного розвитку иієєї категорії дітей є необхідним, оскільки порушення мовлення в подальшому детермінуватиме проблеми соціалізації та адаптаџії дитини в суспільстві, щчо своєю чергою є необхідною умовою для повноцінного розвитку і розкриття можливостей кожної особистості.

Аналіз існуючих методик по виявленню альтернативної комунікації немовленнєвих дітей продемонстрував відсутність уніфікованої професійної діагностичної методики виявлення рівня оволодіння дитиною комунікативними навичками, а також у зв'язку із потребою педагогів, батьків, інших фахівиів у методичних рекомендаціях щуодо опанування ААС. Перспектива подальшого дослідження вбачається в розробиі та обгрунтуванні відповідних методичних матеріалів з включенням діагностичних $і$ корекційно-розвивальних методик, розробичі та апробації програми розвитку мовлення відповідно до наявних особливостей психофізичного розвитку обраної категорії дітей та віковими періодами.

Ключові слова: альтернативна комунікачія, діти з особливими освітніми потребами, тяжкі порушення мовлення, комплексні порушення розвитку, інтелектуальні порушення.

Oksana BORIAK, orcid.org/0000-0003-2484-1237

Doctor of Pedagogical Sciences, Associate Professor, Professor at the Department of Special and Inclusive Education Sumy State Pedagogical University named after A. S. Makarenko (Sumy,Ukraine) oksana_boriak@ukr.net

Yurii KOSENKO, orcid.org/0000-0003-2723-2031 Candidate of Pedagogical Sciences,

Senior Lecturer at the Department of Special and Inclusive Education Sumy State Pedagogical University named after A. S. Makarenko (Sumy,Ukraine)kosenko75@gmail.com 
Боряк О., Косенко Ю. Альтернативна комунікація як засіь розвитку мовленнєвої...

\section{ALTERNATIVE COMMUNICATION AS A MEANS OF DEVELOPING SPEECH ACTIVITY IN CHILDREN WITH COMPLEX DISORDERS}

The article presents the results of a study of the definition of the concept of "alternative communication" in special pedagogical literature, the substantiation of its influence on the development of speech of children with complex developmental disorders - severe speech disorders caused by intellectual impairments of moderate severity.

The purpose of the article is to investigate and substantiate the advisability of using alternative means of communication as an effective means of developing speech in children with complex disorders.

In the course of the study, it was found that alternative communication is a way to teach and, if possible, compensate for permanent or temporary disorders that lead to a limitation of social life and social interaction of persons with complex developmental disorders in which violations of the perception and reproduction of language and speech are recorded, as oral and written. Alternative means of communication are considered in special education as a means of primary communication for children of different ages that are in the pre-speech period of development; means of communication that partially or completely replace oral speech. It was revealed that today, in special education, the issue of the development of communication skills in children with complex (combined) developmental disorders, namely, intellectual and speech disorders, was not considered. The thesis of the problem of speech activity disorders caused by mental retardation of mild and moderate degrees of severity: causes, mechanisms of occurrence, specificity of the cognitive component. The strategy and tactics of the medical-logo-psycholinguistic and pedagogical stage of the study are determined; characteristics of the content, pedagogical conditions and criteria of differentiated assessment of speech activity of children with mild and moderate degree of mental retardation are given; the indicators of speech disorders are substantiated.

It is necessary to determine the features of the communicative development of this category of children, since speech impairment in the future determines the problems of the child's socialization and adaptation in society, in turn, is a necessary condition for the full development and disclosure of the capabilities of each personality.

Key words: alternative communication, children with special educational needs, severe speech disorders, complex developmental disorders, intellectual disabilities.

Постановка проблеми. Одним із пріоритетних напрямів розвитку національної системи освіти є пошук ефективних шляхів включення дітей із особливими освітніми потребами (ООП) в освітнє середовище, їхню соціалізацію, провідні механізми яких забезпечує мовленнєва діяльність. Серед дітей із ООП найбільшу поширеність мають діти із порушеннями мовлення, у яких ці порушення виступають як первинними (провідними), так і супутніми порушеннями розвитку.

Серед дітей із ООП особливе місце займають діти з інтелектуальним порушеннями (ДІП), серед яких поширюються випадки наявності супутніх порушень розвитку: мовлення, опорно-рухового апарату, сенсорні порушення, розлади спектру аутизму тощо.

Відповідно, постає необхідність здійснення корекційно-розвивальної роботи 3 цими дітьми в двох напрямах: створення передумов мовленнєвого розвитку та розвиток основних функцій - спілкування (комунікативної), пізнавальної і функції регулювання мовленнєвої діяльності.

Аналіз досліджень. Питанню вивчення порушень мовлення присвячені дослідження як вітчизняних, так і зарубіжних провідних науковців: при сенсорних порушеннях, а саме слухового аналізатору (Т. Зикова, В. Кондратенко, К. Коровін, С. Кульбіда, К. Луцько, О. Мартинчук, В. Назарина, О. Таранченко, Л. Тігранова, І. Тимошенко, Л. Фомічова, О. Черкасова, М. Шеремет, Ж. Шиф та інші); при порушеннях зору - А. Арушанова, Ю. Бондаренко, Л. Вавіна, Т. Дегтяренко, О. Жильцова, Н. Крилова, Р. Левіна, Т. Пічугіна, Т. Свиридюк, Є. Синьова, С. Федоренко, В. Феоктістова та інші; при дитячому церебральному паралічі (ДЦП) - Л. Данілова, Е. Данілавічютє, М. Іпполітова, О. Мастюкова, С. Притиковська, О. Приходько, К. Семенова, І. Смирнова, В. Тищенко, Г. Хворова, О. Чеботарьова, А. Шевцов та інші; при розладах аутистичного спектру (РАС) О. Аршатська, Н. Базима, В. Башина, В. Каган, C. Конопляста, I. Логвінова, О. Нікольська, В. Тарасун, В. Тищенко, Т. Скрипник, Г. Хворова, М. Шеремет, Д. Шульженко та інші; при затримці психічного розвитку - Н. Борякова, Т. Вісковатова, Н. Голуб, Т. Датешидзе, Т. Ілляшенко, Н. Королько, І. Мартиненко, І. Марченко, А. Обухівська, I. Омельченко, Т. Сак та інші; при тяжких порушеннях мовлення - В. Галущенко, Н. Голуб, Е. Данілавічютє, Л. Журавльова, О. Качуровська, Ю. Коломієць, С. Конопляста, Н. Лопатинська, I. Мартиненко, І. Марченко, Н. Пахомова, Н. Савінова, А. Савицький, Є. Соботович, В. Тарасун, В. Тищенко, Н. Чередніченко, Т. Швалюк, М. Шеремет та інші. Таким чином, соціальна значущість проблеми використання альтернативної комунікації як ефективного засобу розвитку комунікативної функції мовлення, іiі недостатня науково-теоретична i методична розробленість зумовили вибір теми дослідження. 
Мета статті - дослідити та обгрунтувати доцільність використання альтернативних засобів комунікації як ефективного засобу розвитку мовлення у дітей із комплексними порушеннями. Відповідно до мети було визначено завдання дослідження: 3'ясувати рівень розробки досліджуваної проблеми у спеціальній педагогічній, психологічній, науково-методичній літературі щодо висвітлення поняття «альтернативна комунікація»; обгрунтувати доцільність іiі використання у роботі з дітьми з ООП - 3 комплексними порушеннями розвитку: тяжкими порушеннями мовлення на тлі інтелектуальних порушень помірного ступеня важкості.

У ході дослідження нами було використано наступні методи: аналіз, систематизація, порівняння та узагальнення різних поглядів на досліджувану проблему в галузі спеціальної освіти: психокорекційної педагогіки, логопедії, спеціальної дидактики з метою визначення стану іiї розробленості та перспективних напрямів розв'язання; аналіз психолого-педагогічної документації 3 метою виявлення особливостей перебігу мовленнєвого розвитку дітей $з$ комплексними порушеннями; опитування педагогів: дефектологів, логопедів 3 метою визначення труднощів здійснення корекційно-розвивальної роботи з обраною категорією дітей.

Виклад основного матеріалу. Проблема вивчення й ефективного застосування альтернативних засобів комунікації є надзвичайно актуальною в наш час. Як відомо, порушення психофізичного розвитку (ППФР) на ранніх етапах онтогенезу супроводжуються втрачанням традиційних суспільних каналів передачі суспільного досвіду, що значною мірою утруднює процеси його інтеріоризації. Паралельно кількісному і якісному збільшенню ППФР, який спостерігається в останні десятиліття, актуалізується науково-практичний пошук таких засобів альтернативної комунікації для дітей, кінцевою метою якого $є$ відновлення темпів і якості їх психічного розвитку. Одночасно сьогодні відсутні системні дослідження мовлення дітей із комплексними порушеннями, за яких одне порушення розвитку зумовлює інше, і визначити, яке $з$ зазначених порушень $\epsilon$ первинним, майже неможливо. До таких дітей належать діти з інтелектуальними порушеннями помірного ступеня важкості з тяжкими порушеннями мовлення (алаліями, дизартріями), які потребують альтернативної або підтримуючої комунікації.

У літературних джерелах зазначається, що альтернативна комунікація - це спосіб навчити i, за можливістю, компенсувати постійні чи тимчасові порушення, які призводять до обмеження суспільного життя і соціальної взаємодії осіб з комплексними порушеннями розвитку, за яких фіксуються порушення сприймання і відтворення мови і мовлення, як усного, так і писемного (American SpeechLanguage \& Hearing Association (ASHA), 1989).

Альтернативні засоби комунікації розглядаються в спеціальній освіті як засоби первинної комунікації для дітей різного віку, які знаходяться в домовленнєвому періоді розвитку; засоби комунікації, які частково або повністю замінюють усне мовлення (Калинникова, 2009).

Основне правило альтернативної комунікації можна сформулювати наступним чином: «Людина повинна мати можливість сказати, що хоче, тим способом і з тією швидкістю, з якою може» (Калинникова, 2009).

Відповідно, альтернативна комунікація може застосовуватися в різних напрямах: як постійна, щоденна практика; як тимчасова допомога в період проблем 3 комунікацією; як допоміжний засіб для кращого оволодіння мовленням. Використання додаткової знакової системи, на якій грунтується альтернативна комунікація, сприяє розвитку абстрактного мислення і символічної діяльності, таким чином сприяючи розвитку розуміння і появі вербального (звукового) мовлення.

Основні цілі використання альтернативної комунікації можна визначити як: побудову функціонуючої системи комунікації; розвиток навички самостійно і зрозумілим чином доносити до слухача нову для нього інформацію; розвиток здатності дитини висловлювати свої думки за допомогою символів (Фрост, 2011).

$\mathrm{y}$ словнику «аугментативна комунікаияія» (з англ. - augmentative - додаткова, збільшуюча можливості комунікація). Випадки, в яких використовується аугментативна комунікація: порушення слуху (додаткова комунікація завжди використовувалась в середовищі глухих - це мова жестів); рухові порушення, що створюють моторні труднощі (дизартрія, анартрия, апраксія); інтелектуальні проблеми, що впливають на здатність засвоєння вербальних символів через обмеження можливостей пам'яті, уваги, абстрактного мислення (інтелектуальні порушення різного ступеня важкості); емоційні проблеми і порушення контакту (розлади аутичного спектру), які обмежують здатність до сприйняття слів співрозмовника, а також - здатність висловити думки 3 допомогою абстрактних символів, знаків, вироблених слів; специфічні органічні проблеми артикуляцій (при синдромі Дауна низький тонус артикуляційних м'язів заважає опанувати вербальною промовою); 
Боряк О., Косенко Ю. Альтернативна комунікація як засіь розвитку мовленнєвої...

прогресуючі захворювання (м'язова дистрофія, множинний склероз); придбані захворювання або травми (в результаті аварій або інсульту); тимчасові обмеження мовленнєвих можливостей (трахеотомія тощо) (Колупаєва, 2011).

Засвоєння альтернативних засобів комунікації в будь-якому віці відбувається в процесі педагогічної комунікації (Мартиненко, 2011).

Зазвичай вибір основного комунікативного компонента при відсутності мовлення або тяжких його порушеннях зумовлений завданнями спілкування і можливістю його досягнення (Мартиненко, 2011). Тому прийняття рішення про вибір відповідної системи комунікативної підтримки повинно грунтуватися на первинних навичках дитини в сфері візуального сприйняття, дрібної моторики, немовленнєвої комунікації (спонтанний погляд, наближення до оточуючих людей, міміка, жести тощо), а також - на вже сформованих мотиваційних чинниках і сферах інтересу.

У більшості дітей із комплексними порушеннями розвитку є зазвичай затримка мовлення або тяжкі порушення мовлення, за яких вони уникають можливості використовувати мовлення. Через це важливо використовувати інші методи комунікації ще до появи мовлення, а спроби вживання мовлення з'являться у цієї категорії дітей поступово.

Для ефективного розвитку комунікативної діяльності спеціалісти рекомендують дотримуватись наступних умов: створювати ситуації комунікативної успішності; стимулювати комунікативну діяльність, використовуючи проблемні ситуації; усувати комунікативні труднощі; орієнтуватись на «зону найближчого розвитку» i підвищувати рівень комунікативної успішності; проводити корекційно-розвивальну роботу щодо формування комунікативної компетентності, враховуючи індивідуальні особливості дітей та залучаючи педагогів та сім'ю; мотивувати дітей до висловлювання своїх бажань, почуттів, емоцій, думок за допомогою вербальних та невербальних засобів комунікації; створювати ігрові ситуації, які мотивуватимуть дітей до комунікативної діяльності $з$ дорослими та однолітками; в процесі комунікативної діяльності забезпечувати стратегію підтримки й фасилітації взаємодії педагога 3 дітьми, дітей з однолітками.

Під час використання альтернативної і допоміжної комунікації слід дотримуватись основних принципів роботи:

- принцип «від більш реального до більш абстрактного» передбачає використання спочатку фотографій реального об’єкта, потім площинного зображення цього предмета, а далі, за потреби, символів, піктограм або схем; фахівці у підборі засобів комунікації орієнтуються на реальний рівень розвитку дитини, а не на ії біологічний вік;

- принцип різноманітності символів передбачає суміщення різних систем комунікації (жести, символи, картинки тощо), використовуючи при цьому найбільшу кількість додаткових засобів, що сприятиме кращому розумінню та розвитку вербального мовлення;

- принцип постійної підтримки мотивації передбачає підтримання зацікавленості дитини в процесі комунікації шляхом визначення шкали інтересів кожної дитини та іiї вмінь включатись у процес комунікації;

- принцип функціонального використання комунікації передбачає використання системи альтернативної та допоміжної комунікації залежно від функціональних можливостей дитини (зору, слуху, нюху, рухових можливостей) та можливості iii використання за межами заняття, в повсякденному житті (Бабич, 2014).

Таким чином, проблема розробки засобів альтернативної та допоміжної комунікації, які спрямовані на формування комунікативних навичок у дітей з комплексними порушеннями розвитку, має багатофакторне детермінування.

Для розуміння особливостей комунікації ДІП дошкільного віку з тяжкими порушеннями мовлення (ТПМ) насамперед потрібно обгрунтувати поняття «комунікативні навички» та з'ясувати особливості їх формування у цієї категорії дітей.

Комунікативні навички характеризуються вмінням ефективно сприймати інформацію, адекватно ii інтерпретувати і правильно передавати, що дозволяє дитині доносити свою точку зору дорослим та одноліткам в процесі загальної діяльності та інших форм взаємодії з оточуючим середовищем. Це автоматизовані компоненти комунікативної діяльності, формуванню яких сприяє приклад дорослих, спілкування 3 однолітками, педагогами, батьками. Загалом комунікативні навички забезпечують умови для особистісного розвитку, соціальної адаптації, самостійної комунікативної діяльності дітей. Своєю чергою ступінь сформованості цих навичок впливає на результативність навчання, виховання та розвитку (Васильева, 2006).

За визначенням зарубіжних науковців Д. Шерратт та М. Петер, ефективність комунікації у дітей визначається сукупністю наступних параметрів (Калинникова, 2009): здатністю розуміти і використовувати мову тіла (міміку, рухи, жести тощо) в процесі комунікативної ситуації; вмінням розу- 
міти і використовувати жести відповідно до їх значення; спроможністю використовувати комунікативну допомогу, яка містить об'єкти, фотографії, зображення різних об'єктів, випадків, символів тощо; здатністю слухати і чути співрозмовника; вмінням використовувати мовлення і вокалізації для вираження інтенцій у різних комунікативних ситуаціях.

Недостатність розвитку одного із цих параметрів веде до несформованості комунікативних навичок або до порушень послідовності їх формування, що особливо характерно для ДІП з ТПМ, і проявляється у невмінні використовувати базові комунікативні навички, а саме звертатись 3 проханням, вербально привертати увагу тощо.

Ця категорія дітей часто відтворює репліки однолітків або дорослих без додаткової обробки (явище ехолалії), не розуміє і не вміє використовувати жести відповідно до їх значення, не розуміє звернене мовлення та інструкції, не вміє утримувати в пам'яті операції і способи їх виконання, порушує послідовність дій, відволікається, губить мету діяльності (Синьов та інші, 2008).

Будь-яке порушення негативно впливає на дитину, утруднює процес іiі розвитку. Але значніших зусиль потребують діти 3 комплексними порушеннями, бо поєднання кількох порушень обтяжує їх розвиток значно більшою мірою, чим дітей 3 порушеннями психофізичного розвитку інших категорій. Саме у випадках, коли до інтелектуального порушення, обтяженого різноманітними супутніми порушеннями, додаються певні соціально-педагогічні вимоги, у дитини може виникнути комунікативна напруженість, яка деформує міжособистісні стосунки, викликаючи високу тривожність, аутичність та різного роду поведінкові розлади.

Досліджуючи цю проблему, ми дійшли висновку, що з метою запобігання і подолання труднощів у спілкуванні ДІП з ТПМ в соціумі необхідне активне педагогічне втручання в процес формування комунікативних навичок. Корекційно-розвивальна робота передбачає інтегроване використання всіх засобів комунікації, але мовлення $\epsilon$ найбільш доступним її різновидом, яке активно організує перцептивний і соціальний досвід цієї категорії дітей. Педагогічний вплив має бути спрямований на формування комунікативних навичок шляхом активізації всіх збережених аналізаторів. Це сприятиме активізації їх розумової діяльності, яка впливає на весь хід психічного розвитку дитини (Січкарчук, 2012).

На нашу думку, система АAC повинна полегшувати повсякденне життя, допомагати дитині менше відчувати себе не такою як усі і більше керувати власним життям. Більшості людей, які мають потребу в засобах системи ААC, часто бувають необхідні й інші види допомоги, тому iii введення має бути скоординовано 3 такими послугами, як освіта, соціальна та медична допомога тощо.

У багатьох зарубіжних дослідників зазначається, що система PECS є найбільш ефективною під час навчання комунікативним навичкам. Показовим $€$ порівняння PECS і мови жестів в експериментальних умовах. По-перше, жестова комунікація більше впливає на частоту зорового контакту i кількість вокалізацій, ніж PECS (Anderson, 2002). Однак PECS освоювався швидше, ніж жести, користувачі цієї системи частіше проявляли ініціативу. По-друге, навик використання PECS краще і швидше узагальнювався в різних ситуаціях (Anderson, 2002). Кращі показники генералізації навиків мовлення були підтверджені в результаті порівняльного дослідження (Chambers \& Rehfeldt, 2003; Howlin, 2006).

3 огляду на те, що аналіз існуючих методик щодо виявлення альтернативної комунікації немовленнєвих дітей продемонстрував відсутність уніфікованої професійної діагностичної методики виявлення рівня оволодіння дитиною комунікативними навичками, а також у зв'язку iз потребою педагогів, батьків, інших фахівців у методичних рекомендаціях по опануванню ААC перспектива подальшого дослідження вбачається в розробці та обгрунтуванні методичного посібника «Зошит логопеда для немовленнєвих дітей» з включенням діагностичних і корекційно-розвивальних методик, розробці та апробації програми розвитку мовлення відповідності з новими досліджуваними категоріями дітей та віковими періодами (Бодарєва, 2020).

Висновки. Як свідчить грунтований аналіз психолого-педагогічної літератури, комунікативна діяльність детермінована станом зорового аналізатора та інтелектуального розвитку, цьому питанню присвячено багато фахової літератури. Однак ще й дотепер у спеціальній освіті не розглядалось питання розвитку комунікативних навичок у дітей, які мають комплексні (комбіновані) порушення розвитку, а саме - порушення інтелекту та мовлення. Визначити особливості комунікативного розвитку цієї категорії дітей $є$ необхідним, оскільки порушення мовлення в подальшому детермінуватиме проблеми соціалізації та адаптації дитини в суспільстві, що своєю чергою $є$ необхідною умовою для повноцінного розвитку і розкриття можливостей кожної особистості. 


\section{СПИСОК ВИКОРИСТАНИХ ДЖЕРЕЛ}

1. Бабич Н. М. Допоміжна комунікація як один із засобів формування комунікативних навичок у дітей з порушенням зору та інтелекту. Актуальні питання корекиійної освіти (педагогічні науки). Кам'янець-Подільський : ПП Медобори-2006, 2014. С. 6-14.

2. Бодарєва М. І. Інтерференція PECS і системи П. Гальперіна як оптимізація мовленнєвих розладів. Інноваційна педагогіка. Видавничий дім «Гельветика», 2020. Вип. 25. Том 1. С. 130-132.

3. Васильева Е. С. Использование методики Блисс для формирования элементарной коммуникации у безречевых детей. Дефектология. 2006. № 5. С. 41-44.

4. Калинникова Л. И. Введение в альтернативную и дополнительную коммуникацию. Архангельск: Кира, 2009. $89 \mathrm{c}$.

5. Колупаєва А. А. Діти з особливими освітніми потребами та організація їх навчання : наук.-метод. посіб. Вид. допов. та переробл. Київ : Вид. гр. «АТОПОЛ», 2011. 274 с.

6. Мартиненко I. В. Сучасні логопедичні технології у подоланні мовленнєвих розладів у дітей із порушенням психофізичного розвитку. Логопед. 2011. № 1. С. 41-47.

7. Синьов В. М., Матвєєва М. П., Хохліна О. П. Психологія розумово відсталої дитини: Підручник. Київ : Знання, 2008. $359 \mathrm{c}$.

8. Січкарчук Н. Д. Використання невербальним засобів спілкування на логопедичних заняттях зі старшими дошкільниками з моторною. Науковий часопис імені М. П. Драгоманова. Серія 19. Корекиійна педагогіка та психологія. Київ : НПУ імені М. П. Драгоманова, 2012. № 22. С. 243-245.

9. Фрост Л. Система альтернативной коммуникации с помощью карточек (PECS). Москва : Теревинф, 2011. C. $24-29$.

10. American Speech-Language \& Hearing Association (ASHA). (1989). Competencies for speech-language pathologists providing services in augmentative communication. ASHA, 31, 107-110.

11. Anderson, A. E. (2002). Augmentative communication and autism : A comparison of sign language and the Picture Exchange Communication System. Doctoral dissertation, University of California at Santa Barbara, 2001. Dissertation Abstracts International : Section B : The Sciences and Engineering, 62, 4269.

12. Howlin, P. (2006). Augmentative and alternative communication systems for children with autism. InT. Charman $\&$ W. Stone (Eds.), Social and communication development in autism spectrum disorders. New York: The Guildford Press. pp. 236-266.

\section{REFERENCES}

1. Babych N. M. Dopomizhna komunikatsiia yak odyn iz zasobiv formuvannia komunikatyvnykh navychok u ditei z porushenniam zoru ta intelektu. Aktualni pytannia korektsiinoi osvity (pedahohichni nauky). Kam'ianets-Podilskyi: PP Medobory-2006, 2014. S. 6-14. [Babych N. M. Auxiliary communication as one of the means of forming communication skills in children with visual and intellectual disabilities. Current issues of correctional education (pedagogical sciences). Kamyanets-Podilsky: PE Medobory-2006, 2014. P. 6-14.] [in Ukrainian].

2. Bodarieva M. I. Interferentsiia PECS i systemy P. Halperina yak optymizatsiia movlennievykh rozladiv. Innovatsiina pedahohika. Vydavnychyi dim «Helvetyka», 2020. Vyp. 25. Tom 1. S. 130-132. [Bodareva M. I. Interference of PECS and P. Halperin's system as optimization of speech disorders. Innovative pedagogy. Helvetica Publishing House, 2020. Issue. 25. Volume 1. pp. 130-132.] [in Ukrainian].

3. Vasileva E. S. Ispolzovanie metodiki Bliss dlya formirovaniya elementarnoy kommunikatsii u bezrechevyih detey. Defektologiya. 2006. № 5. S. 41-44. [Vasilyeva E. S. Using the Bliss technique for the formation of elementary communication in speechless children. Defectology. 2006. No. 5. P. 41-44.] [in Russian].

4. Kalinnikova L. I. Vvedenie v alternativnuyu i dopolnitelnuyu kommunikatsiyu. Arhangelsk: Kira, 2009.89 s. [Kalinnikova L. I. Introduction to alternative and additional communication. Arkhangelsk: Kira, 2009. 89 p.] [in Russian].

5. Kolupaieva A. A. Dity z osoblyvymy osvitnimy potrebamy ta orhanizatsiia yikh navchannia : nauk.-metod. posib. Vyd. dopov. ta pererobl. Kyiv: Vyd. hr. «ATOPOL», 2011. 274 s. [Kolupaeva A. A. Children with special educational needs and the organization of their education: scientific method. way. Kyiv:: Type. gr. ATOPOL, 2011. 274 p.] [in Ukrainian].

6. Martynenko I. V. Suchasni lohopedychni tekhnolohii u podolanni movlennievykh rozladiv u ditei iz porushenniam psykhofizychnoho rozvytku. Lohoped. 2011. № 1. S. 41-47. [Martynenko I. V. Modern speech therapy technologies in overcoming speech disorders in children with psychophysical development. Speech therapist. 2011. № 1. S. 41-47] [in Ukrainian].

7. Synov V. M., Matvieieva M. P., Khokhlina O. P. Psykholohiia rozumovo vidstaloi dytyny: Pidruchnyk. Kyiv: Znannia, 2008. 359 s. [Sinyov V. M., Matveeva M. P., Khokhlina O. P. Psychology of a mentally retarded child: Textbook. Kyiv: Knowledge, 2008. 359 p.] [in Ukrainian].

8. Sichkarchuk N. D. Vykorystannia neverbalnym zasobiv spilkuvannia na lohopedychnykh zaniattiakh zi starshymy doshkilnykamy z motornoiu. Naukovyi chasopys imeni M. P. Drahomanova. Seriia 19. Korektsiina pedahohika ta psykholohiia. K.: NPU imeni M. P. Drahomanova, 2012. № 22. S. 243-245. [Sichkarchuk N. D. Use of nonverbal means of communication in speech therapy classes with senior preschoolers with motor. Scientific journal named after M. P. Drahomanov. Series 19. Correctional pedagogy and psychology. K. : NPU imeni M. P. Drahomanova, 2012. № 22. S. 243-245] [in Ukrainian].

9. Frost L. Sistema alternativnoy kommunikatsii s pomoschyu kartochek (PECS). Moskva: Terevinf, 2011. S. $24-29$. [Frost L. Card Alternative Communication System (PECS). Moskva: Terevinf, 2011. S. 24-29] [in Russian].

10. American Speech-Language \& Hearing Association (ASHA). (1989). Competencies for speech-language pathologists providing services in augmentative communication. ASHA, 31, $107-110$. 


\section{Пемагогіка}

11. Anderson, A. E. (2002). Augmentative communication and autism : A comparison of sign language and the Picture Exchange Communication System. Doctoral dissertation, University of California at Santa Barbara, 2001. Dissertation Abstracts International : Section B : The Sciences and Engineering, 62, 4269

12. Howlin, P. (2006). Augmentative and alternative communication systems for children with autism. InT. Charman $\&$ W. Stone (Eds.), Social and communication development in autism spectrum disorders. New York: The Guildford Press. pp. 236-266. 